\title{
INTEGRASI PENDIDIKAN NILAI NILAI KEMANUISIAAN \\ KE DALAM PENBELAJARAN KEWARGANEGARAAN DI SEKOLAH DASAR
}

\author{
I WAYAN SUNARTA \\ SD Sathya Sai Denpasar
}

\begin{abstract}
Humanity Values consisting of Truth, Righteousness, Peace, Love and Non-violence are values that are relevant to the values of national character. The five values are universal values for the entire life. The values can be integrated in learning, either implicitly contained in teaching materials, as well as integrated in the learning activities. Humanity Values that are integrated in the teaching materials can be either matter or the story of a lesson or group lesson are packed in thematic learning. While the integration of Humanity Values in learning activities can be either a game or other learning activities that are full of Values of Humanity or national character values that are taught in elementary school. This study aimed to integrate Education Values of Humanity Values into civics learning in elementary schools. The study design is explorative research with data sources gained from documents such as books and the opinion of experts on educational values of humanity, character education content standards in 2006 content standard. The instrument used to collect data is documentation. Based on the results of the analysis showed that integration of the value of research into the humanity values on Civics learning in elementary school is done by understanding the substance of Competency Standard and Basic Competency.

Keywords: Humanity Values, Civics Learning
\end{abstract}

\section{PENDAHULUAN}

Era globalisasi banyak memberikan manfaat positif bagi umat manusia.dengan kemajuan teknologi banyak kemudahan kemudahan yang didapatkan misalnya dalam bidang

pendidikan,komunikasi,transportasi,ekonom i,pariwisata dan lain lain.Tetapi dampak negatif juga tidak bisa kita pungkiri yaitu adanya degradasi moral yang kita hadapi sehingga sering kita tonton di televisi ataupun di media sosial banyak terjadi kekerasan,kekejaman,penggunaan

narkotika,aborsi,pembuangan bayi,seks bebas,dan lain lain,yang merupakan cerminan bahwa nilai nilai kemanusiaan saat ini sudah mengalami kemerosotan.Padahal Pendidikan saat ini jauh pengalami kemajuan dibandingkan jaman dulu.Di sekolah sudah diajarkan pendidikan Agama,Kewarganegaraan dan pendidikan yang lain yang semuanya menuntun kita untuk menjadi manusia yang seutuhnya.

Dalam kehidupan berbangsa dan bernegara,kita punya Pancasila sebagai dasar Negara.tetapi pada kenyataannya banyak kita saksikan adanya pelecehen pelecehan yang berbau SARA yang bisa memecah belah persatuan dan kesatuan bangsa Indonesia.Dihidupkannya lagi Pendidikan Budi Pekerti secara tidak langsung memberikan anggapan bahwa pendidikan ke warganegaraan yang berfungsi sebagai pendidi- kan moral yang telah berlangsung selama ini dinilai gagal dalam menciptakan ma- nusia yang bermoral dan berakhlak sesuai dengan misi dan tujuannya. Merebaknya praktek-praktek kolusi, korupsi dan budaya nepotisme pada masa pemerintahan Orde Baru hingga pemerintahan saat ini semakin menegaskan tuduhan gagalnya pembelaja- ran pendidikan kewarganegaraan.

Pendidikan budi pekerti mempunyai esensi dan makna yang sama dengan pendidikan nilai nilai kemanusiaan, yaitu membentuk pribadi anak, supaya menjadi manusia yang baik, warga masyarakat, dan warga negara yang baik, sehingga mampu mengantisipasi gejala krisis moral dan berperan dalam rangka pembinaan generasi muda.

Berdasarkan pernyataan tersebut membuktikan bahwa penerapan pendidikan nilai nilai kemanusiaan kedalam pembelajaran nampaknya menjadi suatu keharusan, karena dinilai mampu menjadikan peserta didik menjadi cerdas, melainkan juga mampu menjadikan peserta didik mempunyai budi pekerti dan sopan santun sehingga keberadaannya sebagai anggota masyarakat menjadi bermakna baik 
bagi dirinya maupun masyarakat pada umumnya.

Pendidikan

Kewarganegaraan merupakan salah satu program pendidikan yang memiliki ruang lingkup yang cukup luas dan meliputi sedikitnya tiga domain dalam proses pembangunan karakter, yakni (1) secara konseptual pendidikan kewarganegaraan berperan dalam mengembangkan konsep-konsep dan teori, (2) secara kuriku- ler Pendidikan kewarganegaraan mengembangkan sejumlah program pendidikan dan model implementasinya dalam mempersi- apkan peserta didik menjadi manusia dewasa yang berkarakter melalui lembagalembaga pendidikan, dan (3) secara sosial kultural pendidikan kewarganegaraan melaksanakan proses pembelajaran kepada masyarakat agar menjadi warga negara yang baik. Sebagai bagian dari kurikulum pendidikan nasional yang tertera dalam UU No. 20 tahun 2003 tentang Sisdiknas, pro- gram pendidikan kewarganegaraan berlan- daskan pada Pancasila dan UUD 1945, ber- fungsi mengembangkan kemampuan dan membentuk watak serta peradaban bangsa yang bermartabat dalam rangka mencerdaskan kehidupan bangsa, bertujuan untuk berkembangnya potensi peserta didik agar menjadi manusia yang beriman dan bertakwa kepada Tuhan Yang Maha Esa, berakhlak mulia, sehat, berilmu, cakap, kreatif, mandiri, dan menjadi warganegara yang demokratis serta bertanggung jawab. Hal tersebut menunjukan bahwa pendidikan kewarganegaraan mempunyai peran yang penting dan strategis dalam pelaksanakan pendidikan nilai nilai kemanusiaan

Implementasi pendidikan nilai nilai kemanusiaan ke dalam proses pembelajaran tidak dapat dilaksanakan apabila guru belum bisa mengintegrasikan kedalam perangkat pembe- lajaran. Dalam Pengintegrasian nilai-nilai kemanusiaan kedalam perangkat pembelajaran tidak dapat di integrasikan secara begitu saja, melainkan harus menyesuaikan terlebih dahulu nilai-nilai kemanusiaan dengan standar kompetensi dan kompetensi dasar. Dalam membuat perangkat pembelajaran dalam hal ini RPP guru harus memperhatikan nilai-nilai kemanusiaan yang sesuai dengan tujuan pembelajaran yang tertuang dalam Standar Kompetensi dan Kompetensi dasar.

Dari uraian diatas, dapat dirumuskan permasalahan yaitu Bagaimana pengintegrasian nilai-nilai kemanusiaan ke dalam pembelajaran pendidikan kewarganegaraan di sekolah dasar?

\section{KAJIAN TEORI}

\section{A. Kajian Umum Tentang Pendidikan Karakter dan Nilai nilai kemanusiaan}

1. Karakter adalah pengembangan dari soft skill dalam bidang pendidikan yang cakupannya cukup luas yang telah dikemukakan oleh Badan Standar Nasional Pendidikan (BSNP) yang sampai saat ini telah dihimpun sebanyak 27 butir seperti berikut ini :(1)Kemampuan menyesuaikan diri dengan lingkungan , perubahan dan tantangan, (2)Sikap dan perilaku dalam pergaulan, (3)Kesadaran terhadap situasi, (4)Merintis dan mengelola perubahan, (5) Bekerja sama dengan pihak lain, (6) Menyampaikan pesan dan mendengar pendapat orang lain, (7) Ketaat asasan pada tujuan bersama, (8) Percaya atas kemampuan diri, (9) Keberanian mengambil tindakan, (10) Mengelola konflik dan menyelesaikan perbedaan pendapat, (11) Bertanggung jawab terhadap tindakan pribadi, (12) Berpikir kritis,rasional,dan objektif, (13) Ketaatan mengatur waktu dan melaksanakan tugas, (14)Semangat dan gairah untuk berbuat,(15) Merasakan apa yang dirasakan orang lain, (16) rasa kemanusiaan, (17) Mempengaruhi,membujuk orang lain, (18) Kesiagaan bertindak setiap ada peluang, (19) Gagasan dan penemuan baru yang autentik, (20) Tulus,jujur,

(21) Kepemimpinan, (22) Disukai orang lain, (23) Menyelesaikan masalah,(24) Mengambil resiko yang diperhitungkan,(25) Kepekaan social,(26) Berpikir strategis, berjangka panjang,(27) Dapat dipercaya.(Sayang, 2012)

Selanjutnya Supinah dan Parmi (2011) mendeskripsikan nilai karakter bangsa untuk sekolah dasar sebagai berikut:

a. Religius, adalah sikap dan perilaku patuh dalam melaksanakan ajaran agama yang dianutnya, toleran terhadap pelaksanaan ibadah agama lain, serta hidup rukun dengan pemeluk agama lain.

b. Jujur, adalah perilaku yang menunjukkan dirinya sebagai orang yang dapat dipercaya, konsisten terhadap ucapan dan tindakan sesuai dengan hati nurani.

c. Toleransi, adalah sikap dan tindakan yang menghargai perbedaan, baik perbedaan agama, suku, ras, sikap atau pendapat dirinya dengan orang lain.

d. Disiplin, adalah tindakan yang menunjukkan adanya kepatuhan, ketertiban terhadap ketentuan dan peraturan yang berlaku.

e. Kerja keras, adalah perilaku yang menunjukkan upaya sungguh-sungguh dalam menghadapi dan mengatasi berbagai hambatan belajar, tugas atau yang lainnya dengan sungguh-sungguh dan pantang menyerah. 
f. Kreatif, adalah kemampuan olah pikir, olah rasa dan pola tindak yang dapat menghasilkan sesuatu yang baru dan inovatif.

g. Mandiri, adalah sikap dan perilaku dalam bertindak yang tidak tergantung pada orang lain dalam menyelesaikan suatu masalah atau tugas.

h. Demokratis, adalah cara berpikir, bersikap dan bertindak dengan menempatkan hak dan kewajiban yang sama antara dirinya dengan orang lain.

i. Rasa ingin tahu, adalah sikap dan tindakan yang menunjukkan upaya untuk mengetahui lebih dalam tentang sesuatu hal yang dilihat, didengar, dan dipelajari.

j. Semangat kebangsaan, adalah cara berpikir, bertindak dan cara pandang yang lebih mendahulukan kepentingan bangsa dan negara diatas kepentingan pribadi dan kelompok.

k. Cinta tanah air, adalah cara berpikir, bersikap dan bertindak yang menunjukkan rasa kesetiaan yang tinggi terhadap bangsa dan negara.

1. Menghargai prestasi, adalah sikap dan perilaku yang mendorong dirinya untuk secara ikhlas mengakui keberhasilan orang lain atau dirinya.

$\mathrm{m}$. Bersahabat/komunikatif, adalah tindakan yang mencerminkan atau memperlihatkan rasa senang dalam berbicara, bekerja atau bergaul bersama dengan orang lain.

n. Cinta damai, adalah sikap perilaku, perkataan atau perbuatan yang membuat orang lain merasa senang, tentram dan damai.

o. Gemar membaca, adalah sikap atau kebiasaan meluangkan waktu untuk membaca buku-buku yang bermanfaat dalam hidupnya, baik untuk kepentingan sendiri atau orang lain.

p. Peduli lingkungan, adalah sikap perlaku dan tindakan untuk menjaga, melestarikan dan memperbaiki lingkungan hidup.

q. Peduli sosial, adalah sikap dan tindakan yang selalu memperhatikan kepentingan orang lain dalam hidup dan kehidupan.

r. Tanggung jawab, adalah sikap dan perilaku seseorang yang ditunjukkan dalam melaksanakan tugas sesuai dengan kaidahkaidah yang berlaku.

Sedangkan menurut Jumsai (2008) bahwa nilai-nilai kemanusiaan (Human Values) terdiri dari lima pilar yaitu Kebenaran, Kebajikan, Kedamaian, Kasih Sayang dan Tanpa Kekerasan. Dengan demikian bila kita perhatikan kelima pilar nilai-nilai kemanusiaan ini sangat relevan dengan nilai-nilai karakter yang diuraikan di atas. Sehingga bila nilainilai kemanusiaan ini dapat diintegrasikan dalam bahan ajar akan berdampak positif terhadap perkembangan karakter siswa.

Selanjutnya Jumsai (2008) berpendapat ada beberapa prinsip dasar dalam pembelajaran Nilai-nilai Kemanusiaan (Human Values) secara terpadu sebagai berikut:

1. Nilai-nilai kemanusiaan adalah bagian integral dari semua matapelajaran dan semua kegiatan di sekolah dan di rumah. Bahkan nilai-nilai kemanusiaan merupakan bagian terpadu dari kehidupan manusia.

2. Lima nilai kemanusiaan yaitu Kebenaran, Kebajikan, Kedamaian, Kasih Sayang dan Tanpa Kekerasan merupakan satu kesatuan tidak dapat dipisahkan satu dengan yang lainnya. Jika satu nilai hilang maka semua nilai yang lain akan hilang. Sebagai contoh: jika tidak ada kasih sayang dan belas kasih, maka orang itu tidak mempertimbangkan orang lain terlebih dahulu tetapi lebih mementingkan diri sendiri, maka kebajikan akan hilang. Orang itu akan tidak merasakan kedamaian bila tidak ada cinta kasih. Jika tidak ada kedamaian, maka kesadaran tidak bisa diangkat ke super sadar sehingga nilai kebenaran akan hilang. Tanpa kedamaian, kasih sayang, kebenaran dan kebajikan maka akan terjadi kekerasan (violence).

3. Nilai-nilai kemanusiaan tidak bisa diajarkan, mereka harus dibangkitkan dari dalam diri siswa. Transformasi seseorang tidak bisa terjadi hanya melalui pengajaran, tetapi dapat dicapai melalui upaya-upaya membangkitkan kesadaran diri (selfrealization), yaitu bila nilai-nilai itu muncul dari dalam siswa.

4. Pada kehidupan nyata, segala sesuatu saling berkaitan. Oleh karena itu pengalaman belajar yang baik adalah pendekatan terpadu. Dalam hidup kita sehari-hari, kita tidak hanya memiliki satu nilai sepanjang hari. Contohnya, kebajikan tidak bisa hadir sendirian tetapi ditemukan bahwa kelima nilai kemanusiaan itu saling berkaitan dan hadir pada saat bersamaan.Oleh karena itu suatu kesalahan bila kita hanya mengajarkan satu nilai kemanusiaan pada saat tertentu.

5. Pembelajaran Nilai-nilai Kemanusiaan secara terpadu memberi siswa kemampuan untuk memecahkan masalah dari berbagai perspektif dengan memberikan beragam pengalaman yang saling berkaitan.

6. Pembelajaran Nilai-nilai Kemanusiaan secara terpadu membuka wawasan akan dunia yang lebih luas bagi guru dan siswa membuat proses belajar menjadi jauh lebih menarik. 
Oleh karena itu pengintegrasian nilai-nilai kemanusiaan dalam pembelajaran tematik cukup prospektif dalam mendukung pengimplementasian Kurikulum 2013. Apalagi pada kurikulum tersebut sangat menekankan aspek pembentukan sikap (karakter). Menurut Jumsai (2008) bahwa ada beberapa cara mengintegrasikan nilai-nilai kemanusiaan ke dalam mata pelajaran antara lain:

- Mengungkapkan nilai-nilai yang ada dalam matapelajaran.

- Pengintegrasian langsung dimana nilainilai kemanusiaan menjadi bagian terpadu dari matapelajaran.

- Menggunakan perumpamaan dan membuat perbandingan dengan kejadiankejadian serupa dalam hidup para siswa.

- Mengubah hal-hal negatif menjadi positif.

- Mengungkapkan nilai-nilai melalui diskusi dan brainstorming.

- Menggunakan cerita untuk memunculkan nilai-nilai.

- Memainkan permainan nilai-nilai kemanusiaan.

- Menceritakan kisah hidup orang-orang besar.

- Menggunakan lagu-lagu dan musik untuk mengintegrasikan nilai-nilai.

- Menggunakan drama untuk melukiskan kejadian-kejadian yang berisikan nilainilai.

- Menggunakan berbagai kegiatan seperti kegiatan pelayanan (service), field trip dan klub-klub atau kelompok-kelompok kegiatan untuk memunculkan nilai-nilai kemanusiaan.

Nilai-Nilai Kemanusiaan tersebut dapat diintegrasikan baik dalam proses kegiatan pembelajaran maupun terintegrasikan dalam bahan ajar. Pengintegrasian nilai-nilai kemanusiaan dalam kegiatan pembelajaran, guru dapat memikirkan bentuk-bentuk kegiatan yang membawa dampak pada pembentukan karakter anak didik. Misalnya siswa dibiasanya belajar berkata yang sopan dalam bertanya atau menangggapi pendapat siswa lain. Atau membentuk kegiatan permainan dalam kegiatan pembelajaran yang syarat dengan nilai-nilai kasih sayang atau kebenaran dan lain sebagainya. Oleh karena itu guru diharapkan kreatif dan inovatif dalam merancang kegiatan pembelajaran sehingga memberi dampak pada pembentukan karakter.

Menurut Jumsai (2008) bahwa ada beberapa cara mengintegrasikan nilai-nilai
ADI WIDYA: Jurnal Pendidikan Dasar Volume. 2, Nomor 2 Oktober 2017

ISSN: 2527-5445

http://ejournal.ihdn.ac.id/index.php/AW

kemanusiaan ke dalam matapelajaran antara lain:

a. Mengungkapkan nilai-nilai yang ada dalam matapelajaran.

b. Pengintegrasian langsung dimana nilainilai kemanusiaan menjadi bagian terpadu dari suatu pelajaran.

c. Menggunakan perumpamaan dan membuat perbandingan dengan kejadiankejadian serupa dalam hidup para siswa.

d. Mengubah hal-hal negatif menjadi positif.

e. Mengungkapkan nilai-nilai melalui diskusi dan brainstorming.

f. Menggunakan cerita untuk memunculkan nilai-nilai.

Sebagai contoh dalam pelajaran Pkn membahasa tentang tokoh "Sultan Hasanuddin", setelah bercerita guru mengungkapkan nilai nilai yang didapatkan dari cerita tersebut ,seperti empati,keberanian,Kesantunan dalam bertutur kata,kerja keras, Kejujuran, Ikhlas berbuat dan lain lain.

$\begin{array}{cccc}\text { Demikian } & \text { pula } & \text { halnya } & \text { untuk } \\ \text { matapelajaran } & \text { yang } & \text { lain } & \text { selain }\end{array}$ mengintegrasikan nilai-nilai kemanusiaan (karakter) melalui bahan ajar, juga dapat diintegrasikan dalam kegiatan proses pembelajarannya misalnya melalui permainan atau bentuk aktivitas pembelajaran lain yang memungkinkan untuk mengintegrasikan nilainilai tersebut. Bila setiap bahan ajar dan kegiatan proses pembelajaran sarat dengan integrasi nilai-nilai kemanusiaan (karakter), maka akan memberi prospek positif terhadap revolusi mental bangsa melalui pendidikan.

\section{d. Tujuan Pendidikan Nasional}

Tujuan pendidikan nasional mencerminkan kualitas yang harus dimiliki setiap warga negara Indonesia, dikembangkan oleh berbagai satuan pendidikan di berbagai jenjang dan jalur. Dalam tujuan pendidikan nasional terdapat berbagai nilai kemanusiaan yang harus dimiliki seorang warga negara Indonesia. Oleh karena itu, tujuan pendidikan nasional adalah sumber yang paling operasional dalam pengembangan pendidikan karakter dibandingkan ketiga sumber yang disebutkan di atas (Kemen- diknas 2010: 7). Berdasarkan keempat sumber nilai tersebut maka teridentifikasi sejumlah nilai untuk pendidikan karakter.

\section{B. Pendidikan Kewarganegaraan di Sekolah Dasar}

Pendidikan kewarganegaraan di sekolah dasar dituangkan dalam lampiran 
Permendiknas No. 22 tahun 2006, dalam lampiran tersebut dikemukakan bahwa "mata pelajaran pendidikan kewargenegaraan merupakan mata pelajaran yang memfokuskan pada membentukkan warga nega- ra yang memahami dan mampu melaksanakan hak-hak dan kewajibannya untuk menjadi warga negara Indonesia yang cerdas, terampil, dan berkarakter yang diamanatkan oleh Pancasila dan UUD 1945" sedangkan tujuannya digariskan dengan tegas adalah agar peserta didik memiliki kemampuan sebagai berikut:

1. Berpikir secara kritis, rasional, dan kreatif dalam menanggapi isu kewarganegaraan.

2. Berpartisipasi secara aktif dan bertanggung jawab, dan bertindak secara cerdas dalam kegiatan bermasyarakat, berbangsa, dan bernegara serta anti korupsi.

3. Berkembang secara positif dan demokratis tis untuk membentuk diri berdasarkan karakter-karakter masyarakat Indonesia agar dapat hidup bersama dengan bangsa-bangsa lain.

4. Berinteraksi dengan bangsa-bangsa lain dalam peraturan dunia secara langsung atau tidak langsung dengan memanfaatkan teknologi informasi dan komunikasi.

\section{Integrasi Nilai-nilai Pendidikan Karakter Dalam Pembelajaran}

Menurut kemendiknas (2010: 18), nilai-nilai pendidikan karakater diintegrasikan dalam setiap pokok bahasan dari setiap mata pelajaran. Nilai-nilai tersebut dicantumkan dalam silabus dan RPP dengan melalui cara-cara berikut ini:

a. Mengkaji Standar Komptensi (SK) dan Kompetensi Dasar (KD) pada Standar Isi (SI) untuk menentukan apakah nilainilai budaya dan karakter bangsa yang tercantum itu sudah tercakup di dalamnya.

b. Memilih karakter yang memperlihatkan keterkaitan antara SK dan KD dengan nilai dan indikator untuk menentukan nilai yang akan dikembangkan.

c. Mencantumkan nilai-nilai karakter tersebut ke dalam silabus.

d. Mencantumkan nilai-nilai yang sudah tertera dalam silabus ke dalam RPP.

Berdasarkan hal tersebut dapat disi- $\mathrm{m}$ pulkan bahwa RPP mempunyai peranan penting dalam pengintegrasian nilai-nilai pendidikan karakter ke dalam proses pembelajaran di sekolah. RPP merupakan gambaran tentang pembelajaran yang akan dilakukan dalam proses pembelajaran.

Lebih lanjut Warsono (2010) menjelaskan, adapun langkah-langkah yang ha- rus dilakukan dalam menyususun RPP, se- bagai berikut:

1. Memahami substansi SK dan KD, baik dari ranah kognitif, afektif, maupun psikomotor (jika ada).

2. Menyusun indikator yang didasarkan pada hasil pemahaman SK dan KD.

3. Menyusun alat evaluasi.

4. Menyusun materi ajar.

\section{Memilih metode pembelajaran}

Berdasarkan langkah-langkah di atas dapat dijelaskan bahwa dalam menyusun RPP hal yang perlu dilakukan adalah memahami substansi SK dan KD. Secara kognitif, konsep apa yang ada didalam SK dan KD. Pemahaman konsep dan perilaku yang diharapkan didalam SK dan KD menjadi kunci dalam penyusunan indikator. Dari indikatortersebut akan menjadi acuan dalam menyusun alat evaluasi dan materi ajar. Dari materi ajar akan memandu dalam memilih metode pembelajaran.

\section{METODE}

Penelitian ini merupakan penelitian ekploratif, yaitu salah satu penelitian sosial yang tujuannya untuk memberikan sedikit definisi atau penjelasan mengenai konsep atau pola yang digunakan dalam penelitian. (Neuman: 2003). Tujuan dari penelitian ini adalah untuk menjadikan topik baru lebih dikenal oleh masyarakat luas, memberikan gambaran dasar mengenai topik bahasan, menggeneralisasi gagasan dan mengembangkan teori yang bersifat tentatif.

Data yang dibutuhkan dalam penelitian ini adalah dokumen tentang buku pendidikan karakter dan Standar isi PKn tahun 2006 tentang SK dan KD pendidikan kewarganegaraan di sekolah dasar. Data yang terkumpul kemudian dianalisis dengan cara mengkaji Standar Kompetensi (SK) dan Kompetensi Dasar (KD) pada Standar Isi (SI), kemudian Memilih nilai karakter yang memperlihatkan keterkaitan antara SK dan KD dengan nilai dan indikator. Dengan demikian kita dapat mengetahui nilai-nilai karakter yang sesuai dengan pendidikan kewarganegaraan sekolah dasar.

\section{HASIL DAN PEMBAHASAN}

Nilai kemanusiaan merupakan hal yang paling penting dalam proses pembelajaran 
pendidikan karakter di sekolah dasar terutama mata pelajaran PKn. Pemilihan nilai kemanusiaan ke dalam pembelajaran PKn SD tidak bisa diintegrasikan secara begitu saja, memelainkan harus disesuaikan dengan tujuan pembelajaran PKn. Data nilainilai kemanusiaan yang sesuai dengan pembelajaran PKn di SD diperoleh dengan cara mengkaji Standar Kompetensi (SK) dan Kompetensi Dasar (KD) pada Standar Isi (SI), kemudian memilih nilai karakter yang memperlihatkan keterkaitan antara SK dan KD dengan nilai dan indikator.

Berdasarkan analisis antara SK, KD dan indikator, maka nilai kemanusiaan yang sesuai dengan tujuan pembelajaran PKn SD.

\section{PEMBAHASAN DAN HASIL PENELITIAN}

Hasil yang tercapai dalam penelitian ini adalah tersedianya prototipe berupa pedoman integrasi pendidikan nilai nilai kemanusiaan ke dalam pembelajaran PKn SD. Prototipe inte- grasi pendidikan nilai nilai kemanusiaan ke dalam pembelajaran dapat dijadikan pedoman guru dalam penerapan pendidikan nilai nilai kemanusiaan ke dadalam proses pembelajaran PKn di SD. Dalam bab ini akan didiskusikan hal-hal yang berkaitan dengan hasil penelitian baik yang berhubungan dengan pemilihan nilai kemanusiaan dan pengintegrasian nilai kemanusiaan ke dalam perangkat pembelajaran.

Integrasi Nilai-nilai pendidikan nilai nilai kemanusiaan kedalam pembelajaran PKn SD

Penelitian ini menghasilkan prototipe berupa pedoman integrasi pendidikan nilai nilai kemanusian ke dalam pembelajaran PKn sekolah dasar. Diskusi hasil penyusunan prototipe tentang integrasi pendidikan nilai nilai kemanusiaan ke dalam pembelajaran PKn di sekolah dasar diuraikan sebagai berikut.

1. Integrasi pendidikan karakter ke dalam pembelajaran PKn di SD

Pengintegrasian nilai-nilai pendidikan kemanusiaan ke dalam pembelajaran PKn SD dapat dilakukan dengan cara mencantumkan nilai-nilai kemanusiaan kedalam silabus dan RPP. Dalam mencantumkan nilai-nilai kemanusiaan kedalam Silabus dan RPP langkah yang dilakukan, yaitu :
1) Memahami substansi $S K$ dan $K D$, baik dari ranah kognitif, afektif, maupun psikomotor (jika ada).

2) Menyusun indikator yang didasarkan pada hasil pemahaman SK dan KD.

3) Menentukan nilai kemanusiaaan yang memperlihatkan keterkaitan antara SK dan KD dengan nilai kemanusiaan dan indikator.

4) Menyusun alat evaluasi.

5) Menyusun materi ajar.

6) Memilih metode pembelajaran.

Dalam mencantumkan nilai-nilai karakter kedalam Silabus dan RPP hal yang perlu dilakukan yaitu, memahami substansi SK dan KD. Secara Kognitif, konsep apa yang ada di dalam SK dan KD. Kemudian memahami konsep dan perilaku yang diharapkan di dalam SK dan KD menjadi kunci dalam penyusunan indikator. Dari indikator tersebut akan menjadi acuan dalam menyusun alat evaluasi dan materi ajar. Dari materi ajar akan memandu dalam memilih metode pembelajaran.

\section{PENUTUP}

Dengan memperhatikan proses integrasi nilai-nilai pendidikan kemanusiaan dan hasil penelitian, dapat disimpulkan bahwa nilainilai kemanusiaan yang diintegrasikan ke dalam mata pelajaran PKn di SD, yaitu: Kebenaran,kebajikan,kasih

sayang,kedamaian dan tanpa kekerasan.Pengintegrasian nilai-nilai pendidikan kemanusiaan ke dalam pembelajaran PKn SD dapat dilakukan dengan cara men- cantumkan nilai-nilai kemanusiaan ke dalam silabus dan RPP. Dalam mencantumkan nilai-nilai kemanusiaan kedalam Silabus dan RPP hal yang perlu dilakukan yaitu, memahami substansi SK dan KD. Secara Kognitif, konsep apa yang ada di dalam SK dan KD. Memahami konsep dan perilaku yang diharapkan di dalam SK dan KD menjadi kunci dalam penyusunan indikator. Dari indikator tersebut akan menjadi acuan dalam menyusun alat evaluasi dan materi ajar. Dari materi ajar akan memandu dalam memilih metode pembelajaran.

\section{DAFTAR PUSTAKA}

Depdiknas. 2008. Pengembangan Silabus Dan Rencana Pelaksanaan Pembelajaran Dalam KTSP. (Arifayip.blogspot.co.id diakses 15 juni 2016) 
ADI WIDYA: Jurnal Pendidikan Dasar

Volume. 2, Nomor 2 Oktober 2017

ISSN: $2527-5445$

Depdiknas 2003. Undang-undang Nomor 20 Tahun 2003 tentang Sistem Pendidikan Nasional, (qoqoasroku.blogspot.co.id, diakses 15 juni 2016)

Jumsai,Model Pembelajaran Nilai Nilai Kemanusiaan Terpadu : Pendekatan yang Efektif Untuk

Mengembangkan Nilai- Nilai

kemanusiaan atau Budi Pekerti pada Peseta

Didik. Yayasan Pendidikan Sathya Sai Indonesia : Jakarta

Kemendiknas 2010.Pengintegrasian pendidikan karakter,(https;/amilafi 226.wordpress.com,diakses 15 Juni 2016)

Neuman, CW. Cawrence. 2003. Social Research Methods: United States of America. (https//www.pearsonhighered.com,diakses 15 Juni 2016)
http://ejournal.ihdn.ac.id/index.php/AW

Peggy J.J ,2010.Memupuk dan mengembangkan nilai spiritual pada anak,Jakarta : Gramedia

Permendiknas No. 22 tahun 2006 tentang Standar Isi: Lampiran Standar Isi Pendidikan Kewarganegaraan (PKn)(https/ bagawanadiyasa.wordpress.com)

Rusdi, Sandi. Perangkat Pembelajaran, ( https;//anrusmath.wordpress.com, di akses 15 Juni 2016).

Sayang Y. 2012.Pembentukan karakter bangsa melalui pendidikan dan pengabdian bernuansa spiritual.Surabaya :Paramita

Yaumi. 2014 .Prinsip prinsip desain pembelajaran disesuaikan dengan kurikulum 2013,Jakarta : Kencana 